\title{
Departmental Libraries
} in Divisional Plan

\section{University Libraries}

Mr. Blanchard is librarian, University of California Library, Davis, Calif.

THE ORganization of university librar1 ies according to a broad subject plan is a relatively new development. The first divisional plans were put into effect over ten years ago at the University of Colorado and at Brown University. The University of Nebraska followed suit socn thereafter. A shift to a divisional arrangement is in process or is being considered at other major universities, although the application of the principles of divisional organization will probably vary at all of the institutions. ${ }^{1}$ 'The principal tenets of the divisional plan might be listed as follows:

I. All functions of the library, with the exception of technical processes and top administrative positions, are divided int 3 subject areas. These broad areas are usually thrce, i.e.: the social sciences, the humanities, and science and technology. The divisional librarian usually reports to the director of libraries or his assistant and through delegation of authority is responsible for administration, public service, student and faculty contact, book selection and branch or departmental libraries in his subject area.

2. Free and open access to all materials is implicit in the divisional plan. In the central library there is usually a divisional reading room for each subject area con-

1 For an excellent and recent statement on this type of library service see Frank Lundy's, "The Readers' Services, Introduction to a Midtwentieth Century Concept of the University Library" which is chapter 6 of Louis R. Wilson's and Lundy's Report of a Survey of the Library of the University of Notre Dame . . Chicago, American Library Association, 1952. sisting of an open shelf collection carefully selected to represent the best material in the fields covered. There may also be a core stack containing little used items.

3. Public service librarians, or those serving in the divisional reading rooms, are subject specialists rather than reference or circulation librarians.

4. Pedagogically the divisional library is designed to forward the trend away from the "splintered curriculum" and to support the theory of a "general education" which advocates survey courses designed to present the student with the full sweep and implication of broad subject areas. The movement away from the lecture and text-book form of teaching toward a fuller use of a more independent type of study and research has also had much influence on this type of library organization.

Although divisional plan libraries built on a subject approach are relatively new in university library circles a comparable type of organization has been working well for many years at several large American public libraries. The movement was started at the Cleveland Public Library some fifty years ago and was a reaction against the old closed stack idea. It is interesting to note that the open shelf subject plan is in effect a reversion to the primitive library where all materials were kept in reading rooms on open shelves running around the walls.

Since university divisional plan libraries are relatively new they still have unsolved problems-one of the most important being the status of the departmental library. 
From the administrative standpoint departmental collections present no problem since they may very easily be placed under the aegis of the proper divisional librarian. From another viewpoint, however, the departmental library violates the most important canon of the divisional plan-the presentation on open shelves of all important materials in broad subject areas. Such a presentation is difficult if not impossible if the major part of a subject collection is scattered over the campus and grouped together in various narrow categories of knowledge which ignore the ever growing interdependence in all fields of learning.

\section{Departmental Libraries in the Humanities and Social Studies}

Departmental libraries in the areas of the humanities and the social studies have caused little difficulty. Colorado, Nebraska and Brown have all been successful in bringing together most of their collections in these fields and presenting them in divisional arrangements in the main library buildings. The only exception at Nebraska has been the Law Library which has remained in the College of Law building because of its intensive use by a special clientele. It has also been considered necessary at Nebraska to have small laboratory collections in music and architecture which are operated by departmental secretaries and administered by the divisional librarian in the humanities. In general, however, departmental libraries in the humanities and social studies are non-existent or unimportant. This is so because with these disciplines the library is the laboratory. The humanities and social studies faculties, in general, have been very pleased with the divisional arrangement and apparently have no desire to go back to the departmental system. The students, to say the least, have been enthusiastic about the open shelves and the help from subject specialists. Signifi- cant increases in circulation figures at $\mathrm{Ne}$ braska, Colorado and Brown attest to the popularity of the new arrangement.

\section{Departmental Libraries in Science and Technology-The Real Problem}

Departmental libraries in science have presented the most difficult problems since the scientist has the most valid argument for such collections, i.e., the book for much of his research is a laboratory tool and must be used in the laboratory, not the library. This difficulty seems to have been at least partially solved at Colorado and Brown. The following information from the directors of libraries at these institutions explains their handling of the situation.

". . . We have for all practical purposes centralization of science and technology library facilities at the University of Colorado. The materials remaining in the Geology $\mathrm{Li}$ brary are of practically no interest to engineering, chemistry, physics, biology, anthropology, or any other departments. As to the reaction to the centralization, my impression from discussion with various faculty members is that the advantages of centralization of materials, professional supervision, and longer hours of opening for the divisional libraries are generally recognized as outweighing any disadvantages.

"The Engineering School established reading room facilities in the engineering building a couple of years ago with the idea that students would prefer to remain in the building between classes. Copies of personal subscriptions to journals and personal copies of engineering books were placed in the room and study tables and reading space were provided. So little use was made of the room it was discontinued after a brief period. The engineering students apparently prefer to come to the main library and particularly to the Science and Technology Reading Room.

"I am quite sure that there has been a tremendous increase in the student and faculty use since the centralization of library facilities. This is an opinion which lacks actual statistics for use in science and technology materials before centralization. The departmental libraries generally were open for limited peri- 
ods and enrolment before the war and before centralization was a fraction of what it is now. The following circulation statistics for the year July I, 1949 through June 30 , 1950 indicate the use made of library materials in the Science and Technology Reading Room:

$\begin{array}{lr}\text { One day or overnight charges } & 10,752 \\ \text { Two-week charges } & 17,819 \\ \text { Faculty charges } & 2475 \\ \text { Total items charged from room } & 31,046\end{array}$

We also keep account of the number of items shelved from tables in the reading room. The total for this one-year period was 147,064 , which indicates the amount of use of materials from the open-shelves as compared to materials charged from the room. A count is made by the attendant at the desk of the number of people entering the room and this total for the year was 188,267 , the highest total for any of the divisional rooms. The circulation from Science and Technology is the lowest of the four divisional rooms but the number of items used in the room is the second highest.

"Current issues of specialized journals in physics, biology, and mathematics are sent to the departmental offices. The back files of these journals are in the central library and all general scientific periodicals are in the central library.

"The advantages of centralized science and technology library services have been indicated in a preceding paragraph. The only real disadvantage $I$ can see is that occasionally it may be inconvenient for a faculty member to have to come to a central library. However, I feel that a sensible policy in regard to office or laboratory collections will provide materials which are frequently or constantly in use and $I$ think it is an advantage for the faculty member to come to a central collection where he at least takes a chance on being exposed to considerably more material in his own or in related fields than ordinarily would be available in a departmental library. ${ }^{2}$

"In the fall of 1938, Brown consolidated its departmental libraries of biology, psychology and botany to form the Biological Sciences Library. This library is housed in the biological laboratory. The departmental libraries of mathematics, physics, chemistry, geology, and engineering were consolidated and together with the astronomy collections and

${ }^{2}$ Wilson, Eugene H. Letter to J. R. Blanchard of May 22, 1951 (MS) general science and academy publications from the main library form the Physical Sciences Library. This library is housed on the top floor of our chemical research laboratory. Both divisions are administered from the main library. Most orders for new books in these subject fields are placed by the assistants in charge. New periodical subscriptions are generally placed on recommendation of the academic departments.

"At the time the libraries were consolidated there was some opposition by two departments, however, it was not long before most faculty members considered that the longer hours of opening, improved service to students and faculty more than compensated for not having the libraries nearer to their offices and laboratories. The use of the collections by both faculty and students has increased considerably since the libraries were moved.

"We have small laboratory collections of approximately 500 volumes for the Botany Department and at the Observatory. Both of these collections are charged out from the divisional library, all volumes are subject to recall to the division when needed for use there. These collections are for reference in the department and circulation of the volumes is through the divisional library.

"The chief advantages that the divisional $L$ libraries have over departmental libraries as far as our library is concerned, are that we are now able to provide a trained staff, maintain uniform hours for all of our collections. We are able to keep a better check on book ordering and have it done at the proper time. The reference service provided has also improved greatly both in quality and quantity. Further we have been able to eliminate duplicate subscriptions to periodicals and to a smaller extent duplication of books. Formerly, we might have to buy as many as three or four copies of an important monograph while now one or at the most two copies generally satisfy our needs. The book funds saved have been used to strengthen files of periodicals and society publications. It is easier to maintain the two card catalogs than it was to keep up the eight or nine we had to provide under the departmental plan. There are advantages to the faculty and students in that they do not have to go from library to library in order to find all of the material they are interested in. This has been one point that has impressed new faculty members and visiting scholars. 
"I suppose the greatest disadvantage is to the faculty member, who could spend time browsing through the new periodicals more regularly when the library was handier to the departmental offices." 3

It should be noted that Brown has solved its problems through the consolidation of departmental libraries into two divisions housed outside of the central building rather than bringing all collections in science into the main library under one division of science and technology.

There has been less centralization of departmental collections in science and technology at Nebraska than at Brown or Colorado. When the new library building at Nebraska was being planned (shortly before World War II) the faculty agreed that all departmental and some branch libraries, the majority of which were scientific, should be centralized into the new library. Since the completion of the building the Engineering College Library, the Pharmacy Library, the Mathematics and Physics Library, and the Dentistry Library have been moved in. These libraries were centralized with the support and help of the faculty. Laboratory library collections have been established in the College of Pharmacy, the College of Dentistry, and in the Physics Department. The branches that remain outside of Love Library are the Chemistry Library, the Biological Science Library (botany, zoology, bacteriology), and the Geology Library. It is very doubtful that the biological sciences and the chemistry libraries will be centralized in the near future. These departments are strong at Nebraska and their faculties are determined to have their collections close at hand. There are, of course, the other two large scientific libraries on separate campuses, the College of Agriculture Library and the College of Medicine Library, both of which fall un-

\footnotetext{
Jonah, David A. Letter to J. R. Blanchard of June I 2, I 95 I (MS)
}

der the aegis of the Divisional Librarian in Science and Technology.

In spite of the lack of centralization it is felt that the Division of Science and Technology at Nebraska is successful for the following reasons:

1. The administration of the branch libraries in science and the collections in science in the main library are coordinated by the divisional librarian. This prevents extensive duplication of materials, permits interchange of personnel, and promotes better administrative practices. Having an administrator trained in science library work in charge of a university-wide science library service has many advantages.

2. General science publications, of which there are many, can be housed in the main building. Only the richest university can endlessly duplicate copies of such periodicals as Nature, which covers all fields of science.

3. General reference and bibliographical services in science can be concentrated rather than be disbursed and duplicated throughout many branches. The more or less sharp lines of demarcation which formerly existed in the various fields of science are rapidly breaking down. A natural scientist, for instance, often needs to know and use certain literature in the physical sciences. The physicist must often go to the natural sciences for information. The relatively new branch of learning called biophysics is an example of this mingling of the natural and physical sciences. Another hybrid is biochemistry which has assumed great importance in recent years. This overlapping will undoubtedly continue to grow making it increasingly difficult to do teaching and research in one science without making extensive inroads into other fields of learning. Even the social sciences, which some natural scientists used to say were not really sciences at all, have encroached onto the hitherto sacrosanct domain of "real" science. Psychiatry is a famous example. Philippe Le Corbeiller (a mathematician and philosopher, formerly with the French Ministry of Communications and now a teacher of 
communications at Harvard) in a brilliant article, "Stars, Proteins, and $\mathrm{Na}$ tions," published in the Atlantic, ${ }^{4}$ points out this inter-relationship of the natural and the physical sciences with the social sciences. "There is a definite order," he says, "in which sciences have developed in the past and are likely to develop in the future." This idea of the development of the fundamental sciences, each dependent on each and all evolving in a pattern running from the simple to the complex, was originated by Comte and Herbert Spencer. "Spencer's list runs thus: Mathematics, Physics, Chemistry, Biology, Psychology, and Sociology." The thesis is that psychology and sociology, the sciences which are of the most immediate and real importance to man, are the most complex. They are still in a primitive stage of development, whereas mathematics and physics, for instance, have progressed much further. "All sciences," LeCorbeiller says, "will in a distant future eventually merge into one, a sort of sociology which will have absorbed all the natural sciences." This means then that a teacher and research man must go further and further afield and must use an ever wider assortment of periodicals, books, bulletins, periodical indexes and abstract journals if he is to do up-to-date and original work in his specialty. As applied to library science the implication is that the small branch collection specializing in a particular science will either need to grow to an unwieldy and expensive size with much duplication of material in the central libraries and other branches or remain small and unsatisfactory.

4. Selection of materials is improved. Under a departmental library system publications of a general nature and those which happen not to be of particular interest to the faculty at the moment will be overlooked. In the divisional set-up at Nebraska, at least, the Divisional Librarian and his assistants see that these gaps do not occur.

There appears to be no easy way to satisfy all concerned in the handling of sci-

4 LeCorbeiller, Philippe. "Stars, Proteins and Nations," Atlantic Monthly, I $78: 78-83$, December, I 946. ence and technology collections in the divisional library. From the evidence gathered at Nebraska, Colorado and Brown, however, it seems probable that one of the following solutions will work in the majority of situations.

I. Centralize the bulk of the collections into the main library building, being particularly insistent that publications of a general nature which overlap into several fields of science be included. With possibly a few exceptions, indexes, abstract journals and other reference tools should also be kept in the main library and be serviced by subject specialists in the Division of Science and Technology. To satisfy the need of the laboratory worker in the descriptive sciences it is recommended that laboratory libraries be set up wherever necessary. These collections should be kept small and should be administered from the main library. It is felt that the abstract and applied sciences (mathematics, physics, engineering, agronomy, etc.) can be adequately served from the central collection since workers in these areas seldom use the book in the laboratory. The worker in the descriptive sciences (botany, zoology, geology, etc.), however, must often bring the book to the laboratory to compare the specimen with the printed description. Both Colorado and Nebraska are now using systems of laboratory libraries to a limited degree.

2. Consolidate the science collections into two main groups-the biological sciences and the physical sciences-and house them in areas convenient to the faculties concerned. Such an arrangement has been worked out with apparent success at Brown.

\section{Conclusions}

The pattern of development at university divisional plan libraries is still in the process of formulation. It is obvious, however, that departmental libraries are becoming obsolete in systems where the divisional plan is used. In the humanities and the social studies the departmental collection has al- 
most disappeared and is no longer a serious problem. Difficulties still exist in science and technology but are gradually being overcome through centralization of general science materials, provision of a centralized service by librarians trained in science, provision of laboratory or office libraries where necessary and/or the consolidation of science collections into two large groupings contiguous to the departments served.

Future developments in science and in library techniques indicate that even more centralization will take place and that the rapid transmission of printed material through new electronic devices will eliminate the necessity for outlying groups of library materials. The use of microcards, microprint and microfilm will make the central collections more compact. The overlapping of all branches of knowledge, the unitary principle of science, will eventually make large separate collections on the periphery of the campus both inefficient and antiquated.

List of References

Childears, C. L. "Let's Use the Division Arrangement in the New College Library," Library Journal, 69: I082-1083, December I 5, 1944.

Currier, T. F. "Subject'Specialist," College and Research Libraries, $2: 14-21$, December, 1940.

Ellsworth, R. E. "Colorado University's Divisional Reading Room Plan: Description and Evaluation," College and Research Libraries, 2:103-109, March, I94I.

Hanson, J. C. M. “Central versus Departmental Libraries," Library Quarterly. I 3:1 32-135, April, I943. Jesse, W. H. "Divisional Organization," Journal of Higher Education, 1 5:459-464, December, I 944.

Jonah, David A. Letter to J. R. Blanchard of June I 2,

I951. (MS) "What Kind of Divisional Reading Rooms?" College and Research Libraries, 8:17-19, January, I 947.

LeCorbeiller, Philippe. "Stars, Proteins and Nations," Atlantic Mont'lly, 178:78-83, December, I 946.

Litchfield, D. H." "Departmental and Divisional Libraries," College and Research Libraries, 2:237-240, June, I 941 .

McAnally, A. M. "Co-ordinating the Departmental Library System," Library Quarterly, 2I:I13-II9, April, 195I.

Sharpe, J. M. "Divisional Reading Rooms in the Small Liberal Arts College," College and Research

Libraries, 2:55-57, December, 1940.
Thompson, L. S. "Historical Background of Departmental and Collegiate Libraries," Library Quarterly, 1 $2: 49-74$, January, I 942 .

Wilson, Eugene $\mathrm{H}$. Letter to J. R. Blanchard of May

Wilson, Louis R. and Lundy, Frank A. Report of a Survey of the Library of the University of Notre Dame. . Chicago, American Library Association, I 952.

\section{Current Serial Records}

(Continued from page 242)

checker had prior to the experiment, each one showed an increase in production when she changed to the $3 \times 5$ file, and in not a single case was there a decrease. Since the $3 \times 5$ files are considerably cheaper and require less space than the visible files, it seems that the burden of proof of efficiency should be placed on the more expensive method rather than on the more economical method. This is equally true of tub files, rotary files and other types of serial record files. According to this experiment, the $3 \times 5$ file is at least as efficient, when properly applied, as any other type of file, offers a number of advantages over other types of files, and costs a great deal less in money, space, and human effort. Until there is clear evidence that other types of files can supply advantages which would justify their additional cost and space, the USDA Library will use old-fashioned $3 \times 5$ card files for its Current Serial Records. 